\title{
ANALISIS KEANEKARAGAMAN JENIS BURUNG AIR DI DIVISI I DAN DIVISI II PT. GUNUNG MADU PLANTATIONS KABUPATEN LAMPUNG TENGAH PROVINSI LAMPUNG
}

\section{ANALYSIS OF THE DIVESITY SPECIES WATER BIRDS IN DIVISI I AND DIVISI II GUNUNG MADU PLANTATIONS INC. LAMPUNG TENGAH REGENCY LAMPUNG PROVINCE}

\author{
Oleh/ by: \\ Apri Hidayat, Bainah Sari Dewi \\ Jurusan Kehutanan Fakultas Pertanian Universitas Lampung \\ Jl. Soemantri Brojonegoro No. 1 Bandar Lampung \\ Email : Apri.hidayat58@gmail.com \\ HP: +6282280725936
}

\begin{abstract}
ABSTRAK
PT. Gunung Madu Plantations (GMP) merupakan perkebunan yang memiliki banyak keanekaragaman hayati salah satunya yaitu burung air yang dijaga atau dilindungi oleh perusahaan. Divisi I dan Divisi II merupakan salah satu areal yang di dalamnya terdapat berbagai jenis burung air. PT. GMP belum memiliki data base tentang keanekaragaman burung air pada areal tersebut, sehingga penelitian ini penting dilaksanakan untuk menganalisis keanekaragaman jenis burung air pada areal Divisi I dan Divisi II PT. GMP. Penelitian ini dilakukan pada Bulan Oktober-November 2015 menggunakan metode titik hitung (Point Count). Berdasarkan hasil penelitian ditemukan 10 spesies burung air dengan total-individu 3420 individu yang berasal dari 4 famili yaitu Ardeidae, Alcedinidae, Anatidae dan Rallidae. Indeks keanekaragaman (Diversity Index) sebesar $\left(\mathrm{H}^{\prime}=2,137\right)$, maka dari hasil tersebut tergolong dalam keanekaragaman yang sedang dan dalam kondisi yang stabil dengan indeks kesamarataan (Evenness Index) sebesar $(\mathrm{J}=0,928)$.
\end{abstract}

Kata kunci: burung air, keanekaragaman, titik hitung.

\begin{abstract}
Gunung Madu Plantations (GMP) Inc. contained high biodiversity, one of that is water birds in its plantation. Division I and Division II are known as the places where diverse water birds inhabited. Gunung Madu Plantation Inc. It self didn't have database of water birds biodiversity yet. According to these, the research need to be done to analyze water birds biodiversity in Division I and Division II of GMP Inc. The research was conducted in October-November 2015, which used of point count method. The study showed about 10 species were found with total individual about 3420 individual, which included within 4 families; Ardeidae, Alcedinidae, Anatidae and Rallidae. The biodiversity index about $\left(\mathrm{H}^{\prime}=2,137\right)$, which categorized as mediocre level, in stable condition and eveness point about $(J=0,928)$.
\end{abstract}

Keywords: biodiversity, water birds, point count. 


\section{PENDAHULUAN}

Burung adalah salah satu jenis satwa yang sangat terpengaruh keberadaannya akibat alih guna lahan hutan, terutama pada lahan-lahan monokultur seperti perkebunan kelapa sawit dan karet. Hilangnya pohon hutan dan tumbuhan semak, menyebabkan hilangnya tempat bersarang, berlindung dan mencari makan berbagai jenis burung. Sementara, burung memiliki peran penting dalam ekosistem antara lain sebagai penyerbuk, pemencar biji, pengendali hama. Burung juga seringkali digemari oleh sebagian orang dari suara dan keindahan bulunya (Ayat, 2011).

Burung air merupakan jenis burung yang seluruh aktifitas hidupnya berkaitan dengan daerah perairan atau lahan basah (Elfidasari, 2007). Burung air (water fowl) dapat diartikan sebagai jenis burung yang secara ekologis keberadaannya bergantung pada lahan basah.

Selama ini konservasi burung di Indonesia masih terpusat pada kawasan-kawasan konservasi yang ditetapkan pemerintah, seperti di dalam cagar alam, suaka margasatwa dan taman nasional. Namun demikian, terdapat burung-burung yang hidup di luar kawasan konservasi seperti hutan tanaman, perkebunan, pemukiman, areal persawahan dan lainnya (Dewi, 2005).

PT. Gunung Madu Plantations merupakan salah satu perkebunan yang didalamnya terdapat berbagai jenis burung air. Berkaitan dengan itu dibutuhkan data dan informasi mengenai keanekaragaman jenis burung air yang ada di PT Gunung Madu Plantations yang dapat bermanfaat bagi stakeholder terkait untuk upaya konservasi di masa yang akan datang.

\section{METODE PENELITIAN}

Penelitian ini dilakukan pada bulan Oktober-November 2015 di PT Gunung Madu Plantations, Kabupaten Lampung Tengah, Provinsi Lampung. Metode yang digunakan yaitu metode kombinasi titik hitung (Point Count) (Bibby, Jones dan Marsden, 2000). Gambar lokasi pengamatan disajikan pada Gambar 1 dan Gambar 2.

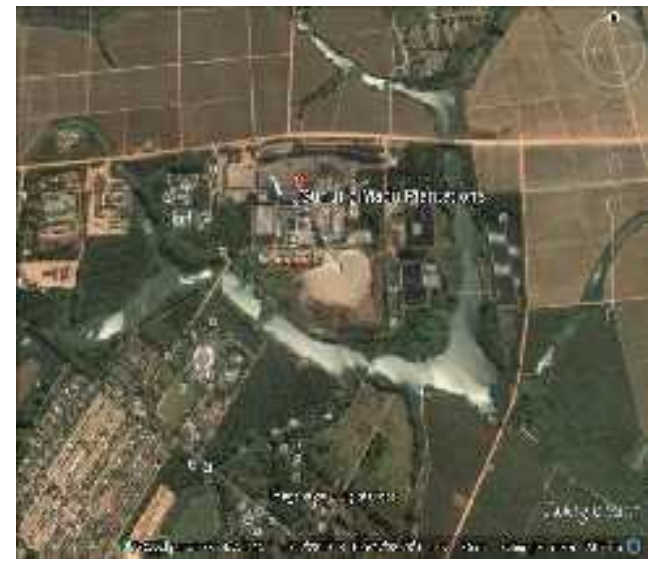

Gambar 1. Lokasi point count 1 dan 2 di Divisi II

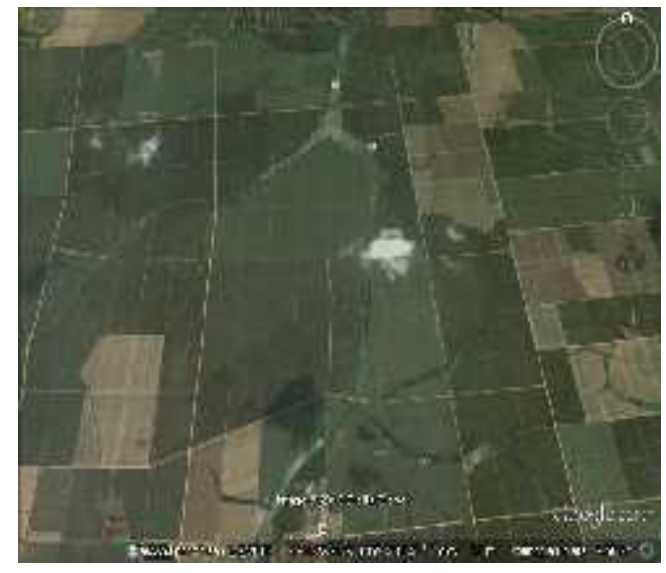

Gambar 2. Lokasi point count 3 dan 4 Divisi I

Pelaksanaan dilakukan dengan diam pada titik yang telah ditentukan kemudian mencatat perjumpaan terhadap burung. Parameter yang diukur yaitu jenis dan jumlah. Pengamatan menggunakan empat titik hitung/stasiun pengamatan. Titik hitung berada dalam 
lokasi yang berbeda-beda. Pada setiap titik hitung waktu yang digunakan dalam melakukan pengamatan adalah 45 menit dan 15 menit untuk pindah ketitik lainnya. Pada setiap titik dalam titik pengamatan dicatat setiap jenis burung yang dijumpai dan jumlahnya.

\section{HASIL DAN PEMBAHASAN}

\section{A. HASIL PENELITIAN}

Terdapat 10 spesies burung air dengan total individu 3.420 individu yang berasal dari 4 famili yang disajikan dalam Tabel 1 .

Tabel 1. Spesies-spesies burung yang terdapat di Divisi I dan Divisi II PT GMP

\begin{tabular}{llllr}
\hline No & Nama Spesies & \multicolumn{1}{c}{ Nama Ilmiah } & \multicolumn{1}{c}{ Famili } & Jumlah \\
\hline 1 & Cangak merah & Ardea purpurea & Ardeidae & 228 \\
\hline 2 & Cekakak sungai & Todirhamphus chloris & Alcedinidae & 160 \\
\hline 3 & Cekakak belukar & Halcyon smyrnensis & Alcedinidae & 77 \\
\hline 4 & Belibis kembang & Dendrocygna arcuata & Anatidae & 292 \\
\hline 5 & Raja Udang Biru & Alcedo coerulescens & Alcedinidae & 171 \\
\hline 6 & Blekok sawah & Ardeola speciosa & Ardeidae & 578 \\
\hline 7 & Mandar Besar & Porphyrio porphyrio & Rallidae & 469 \\
\hline 8 & Kareo padi & Amaurornis phoenicurus & Rallidae & 229 \\
\hline 9 & Kuntul besar & Egretta alba & Ardeidae & 637 \\
\hline 10 & Kuntul kecil & Egretta garzetta & Ardeidae & 579 \\
\hline \multicolumn{2}{l}{ Total Individu } & & \multicolumn{2}{c}{ 2,137 (Sedang) } \\
\hline \multicolumn{2}{l}{ Indeks Keanekaragaman $\left(\mathrm{H}^{\prime}\right)$} & \multicolumn{2}{l}{0,928 (Stabil) } \\
\hline \multicolumn{2}{l}{ Indeks Kesamarataan $(\mathrm{J})$} & &
\end{tabular}

Indeks keanekaragaman dan indeks kesamarataan disajikan pada Tabel 2.

Tabel 2. Indeks keanekaragaman dan indeks kesamarataan burung pada setiap lokasi pengamatan dengan empat titik hitung.

\begin{tabular}{crrr}
\hline $\begin{array}{c}\text { Titik } \\
\text { (Point Count) }\end{array}$ & $\begin{array}{c}\text { Jumlah } \\
\text { Spesies }\end{array}$ & $\begin{array}{c}\text { Indeks } \\
\text { Keanekaragaman }\end{array}$ & Indeks Kesamarataan \\
\hline Point Count 1 & 8 & 1,853 & 0,891 \\
Point Count 2 & 9 & 2,052 & 0,934 \\
Point Count 3 & 8 & 1,890 & 0,909 \\
Point Count 4 & 9 & 1,997 & 0,960 \\
\hline
\end{tabular}

Tabulasi hasil perhitungan indeks kesamaan (Similarity of index) disajikan pada Tabel 3.

Tabel 3. Nilai indeks kesamaan spesies antar point count/stasiun pengamatan

\section{$\begin{array}{lllll}\text { Titik } & \text { Point Count } 1 & \text { Point Count } 2 & \text { Point Count } 3 & \text { Point Count } 4\end{array}$}

\section{(Point Count)}

\begin{tabular}{|c|c|c|c|c|}
\hline Point Count 1 & - & 0,823 & 0,750 & 0,750 \\
\hline Point Count 2 & - & - & 0,823 & 0,823 \\
\hline Point Count 3 & - & - & - & 0,750 \\
\hline Point Count 4 & - & - & - & - \\
\hline
\end{tabular}




\section{B. PEMBAHASAN}

\section{Kelimpahan Spesies}

Cekakak belukar (Halcyon smyrnensis) selama penelitian ditemukan sering kali sedang terbang rendah dengan lincahnya lalu hinggap dan bertengger di ranting pohon dan tunggak-tunggak pohon mati, berwarna dominan biru dan coklat. Menurut Mac Kinnon, Phillips dan Balen (2010), cekakak belukar berukuran sedang, panjang tubuh total (diukur dari ujung paruh hingga ujung ekor) sekitar $27 \mathrm{~cm}$ dengan dagu, kerongkongan dan dada berwarna putih, kepala, leher dan perut hingga pantat coklat merah.

Cekakak sungai (Todirhamphus chloris) selama penelitian ditemukan terbang rendah dan bertengger di ranting pohon dan tunggak-tunggak pohon mati, berwarna dominan biru dan putih. Burung ini dijumpai di setiap stasiun lokasi penelitian. Menurut Mac Kinnon et. al (2010), cekakak sungai berukuran tubuh sedang $(24 \mathrm{~cm})$ dengan mahkota, sayap, punggung, dan ekor biru kehijauan berkilau terang.

Belekok Sawah (Ardeola speciosa) pada saat pengamatan burung ini ditemukan sedang berdiam diri dipinggiran lebung yang berlumpur. Menurut Mac Kinnon et. al (2010) burung yang berukuran kecil $(45 \mathrm{~cm}$ ) bersayap putih, kepala dan dada kuning tua, punggung nyaris hitam, tubuh bagian atas lainnya berwarna coklat bercoret-coret, tubuh bagian bawah putih, burung ini hidup di daerah berair.

Cangak Merah (Ardea purpurea) ditemukan sedang terbang diatas sambil mengeluarkan suara yang khas "uak" dengan berualang-ulang kali. Menurut Mac Kinnon et. al (2010) burung berukuran besar $(80 \mathrm{~cm})$ memiliki warna abu-abu, coklat berangan. Topi Cangak hitam jambul menjuntai, jika sudah dewasa terdapat garis hitam menurun sepanjang leher yang merah karat.

Belibis kembang (Dendrocygna arcuata) saat penelitian ditemukan sedang berdiam diri diembung, berukuran tubuh sedang dan berwarna coklat gelap dan merah. Menurut Mac Kinnon et. al (2010) belibis kembang berukuran sedang (45 cm) dengan kepala atas dan leher belakang coklat gelap sedangkan bagian lainnya lebih pucat,'

Kuntul kecil (Egretta garzetta) memiliki ciri ukuran sedang $(60 \mathrm{~cm})$, berbulu putih. dan kaki hitam, mencari makan dalam kelompok yang tersebar. Menurut Elfidasari dan Junardi (2005) bahwa kuntul kecil merupakan hewan pemangsa ikan dan umumnya memiliki kebiasaan khusus ketika mencari makan, yaitu dengan cara berdiri pada suatu tempat atau mengikuti mangsa.

Raja Udang Biru (Alcedo coerulescens) pada saat pengamatan terlihat bertengger ditunggak-tunggak pohon mati disekitar lebung. Menurut Mac Kinnon et. al (2010) burung berukuran sangat kecil $(14 \mathrm{~cm})$ berwarna biru mencolok dan putih ini memiliki nada cukup tinggi, cicitan dua nada "tiiw-tiiw" yang dikeluarkan sewaktu terbang, bertengger pada pohon di pinggir aliran air kecil, tambak, dan hutan mangrove.

Kareopadi (Amaurornis phoenicurus) pada saat pengamatan ditemukan dibawah sawit dan semak-semak disekitar lebung. Burung ini sering terlihat di tepi jalan mengedap-endap ke semak semak dekat air. Menurut Mac Kinnon et. al (2010) burung yang berukuran besar $(30 \mathrm{~cm})$ berwarna abu-abu dan putih mencolok ini umumnya hidup sendirian di pinggir danau, tepi sungai, hutan mangrove dan sawah.

Mandar Besar (Porphyrio porphyrio) ditemukan di areal tebu dan sawit, dengan jalan terbang rendah secara berpasangan untuk mencari makan di sekitar aliran air dan kembali bersembunyi di semak-semak serta mengeluarkan suara "wak-wak-wak". Menurut Mac Kinnon et. al (2010) burung yang berukuran besar $(42 \mathrm{~cm})$ tubuh pendek gemuk berwarna biru keunguan dengan paruh besar berwarna merah ini adalah burung penghuni rawa-rawa dan danau. 
Kuntul Besar (Egretta alba) pada saat pengamatan ditemukan berada disekitaran lebung untuk mencari makan. Menurut Mac Kinnon et. al (2010) burung yang berukuran besar, memiliki leher bersimpul, pada saat berbiak paruhnya berwarna hitam dengan kaki merah serta kulit muka abu-abu sedangkan pada waktu tidak berbiak paruh dan kulit muka berwarna kuning dengan kaki berwarna hitam. Grafik jumlah individu burung pagi hari selama 14 hari penelitian di Divisi I dan Divisi II disajikan pada Gambar 3.

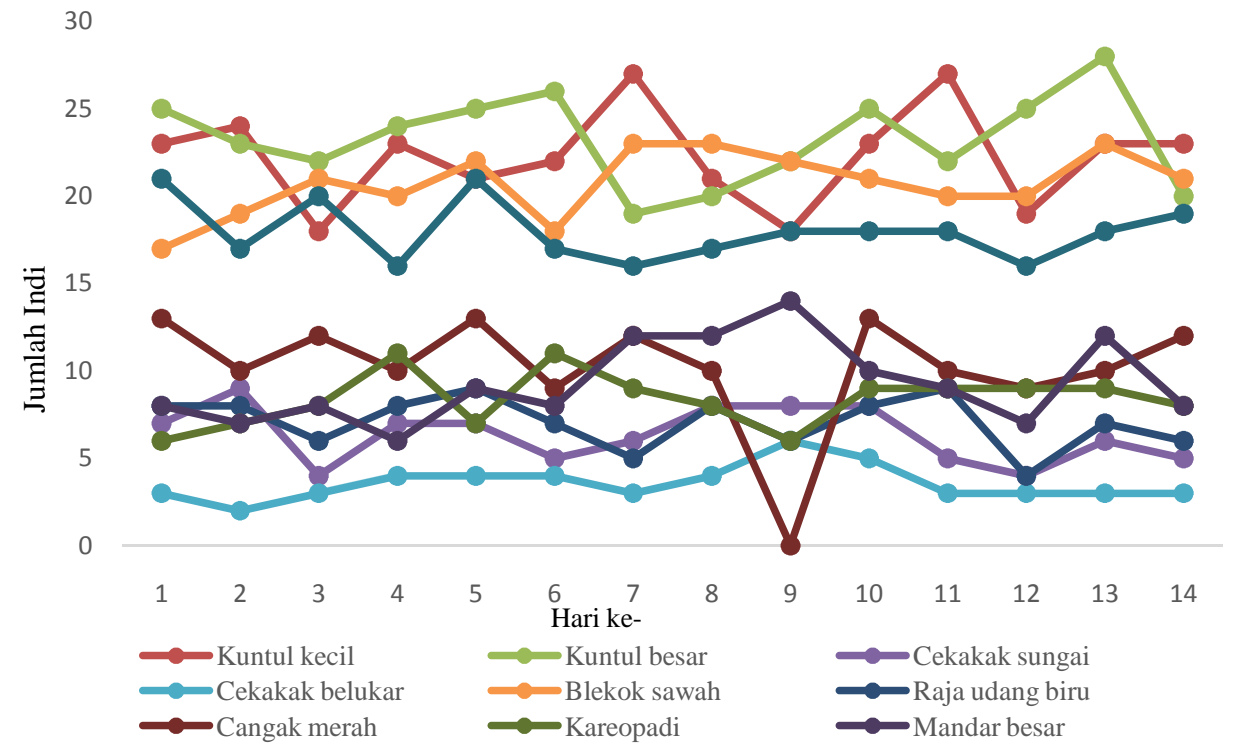

Gambar 3. Grafik jumlah individu burung pagi hari selama 14 hari

Jumlah individu burung yang ditemukan pada pagi hari lebih besar dibandingkan dengan sore hari, hal ini diduga karena pada pagi hari, jenis-jenis burung diurnal sedang memulai aktifitas hariannya, terutama mencari makan. Sedangkan pada sore hari terdapat kecenderungan beberapa jenis burung sedang istirahat atau melakukan aktifitaslainnya seperti bertengger atau berdiam diri (Rusmendro, 2009). Famili Ardeidae merupakan spesies-spesies burung air, burung air sangat bergantung pada lahan basah untuk melangsungkan hidupnya, oleh karena itu diduga burung-burung dalam famili Ardeidae ini sangat menyukai areal tersebut sebagai tempat mencari makanan dan tempat bersarang. Menurut penelitian yang dilakukan Watalee, Ningsih dan Ramlah (2013) dominannya famili ardeidae dipengaruhi oleh tipe habitat yang berawa yang terdapat banyak genangan air sehingga juga terdapat banyak jenis ikan yang hidup yang menjadi pakannya. Grafik jumlah individu burung sore hari selama 14 hari penelitian di Divisi I dan Divisi II disajikan pada Gambar 4.

Berdasarkan gambar 4 jenis burung dengan jumlah individu tertinggi pada pengamatan sore hari adalah jenis burung dari famili Ardeidae sedangkan jenis burung dengan jumlah individu terengah adalah famili Alcedinidae, hal ini dapat disebabkan oleh dua faktor yaitu penggunaan habitat sebagai tempat mencari makan dan tempat beristirahat. Darmawan (2006) mengatakan bahwa burung yang hanya ditemukan pada satu atau beberapa habitat saja dimungkinkan karena jenis tersebut hanya mampu menempati tipe habitat tertentu atau dikarenakan jenis tersebut memiliki populasi yang cukup rendah. Menurut Firdaus, Setiawan dan Rustiati (2014), daya dukung variasi vegetasi merupakan salah satu faktor yang menghubungkan antara keanekaragaman spesies burung dan keseimbangan komunitas, yaitu jika keanekaragaman tinggi, maka keseimbangan komunitasnya juga tinggi. 


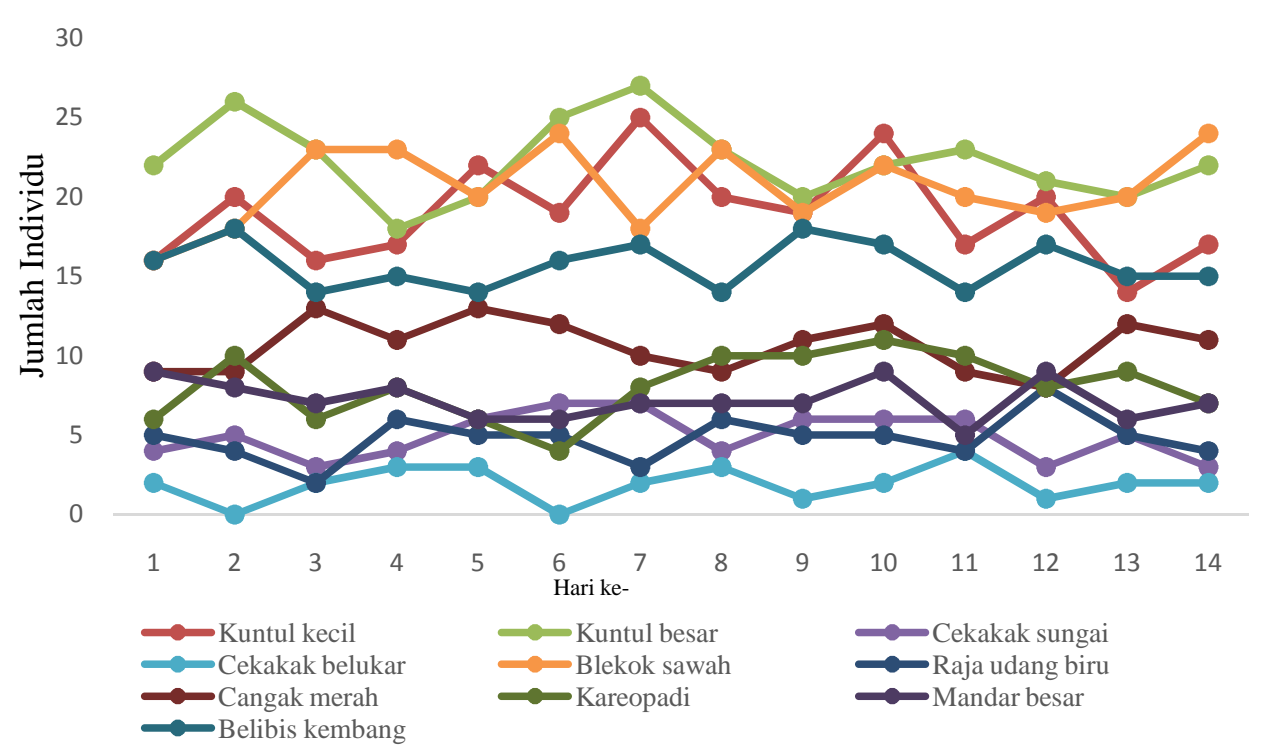

Gambar 4. Grafik jumlah individu burung sore hari selama 14 hari

\section{Keanakaragaman Spesies}

\section{a. Indeks Keanekaragaman}

Grafik indeks keanekaragaman (H') burung air di empat titik hitung disajikan pada Gambar 5.

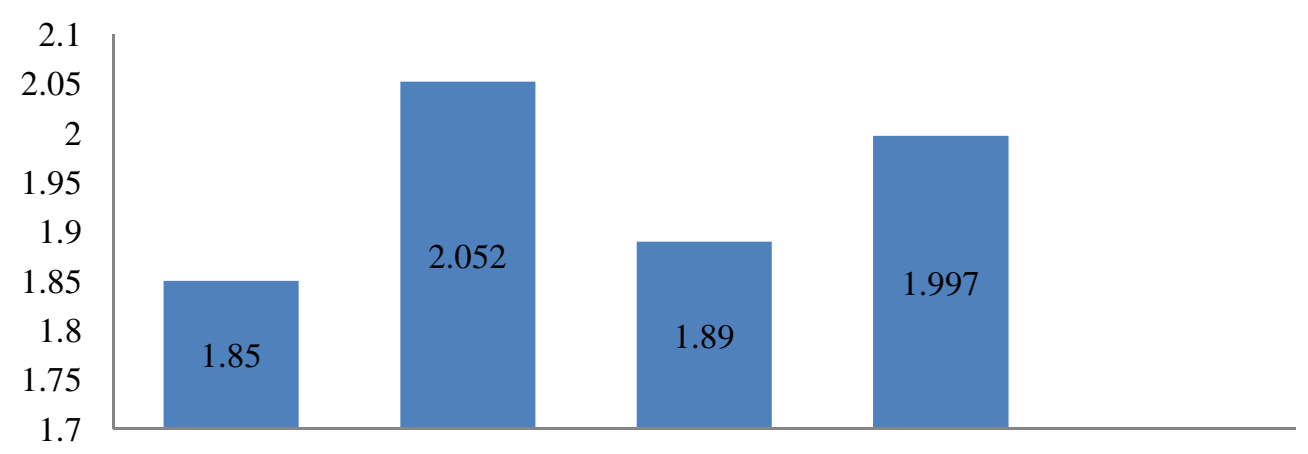

point count 1 point count 2 point count 3 point count 4

Gambar 5. Grafik indeks keanekaragaman (H') burung air di empat titik hitung (Point Count).

Gambar menunjukkan bahwa pada point count 2 memiliki tingkat keanekaragaman yang paling tinggi sedangkan pada point count 1 memiliki tingkat keanakeragaman terendah, hal ini diduga karena pada point count 1 berada di area sekitar pemukiman dan pabrik, sehingga burung-burung terganggu dan terancam dengan aktivitas-aktivitas manusia yang terjadi di sekitarnya, sedangkan point count 3 memiliki tingkat keanekaragaman tertinggi diduga karena selain terdapat banyak spesies pohon juga cukup jauh dengan areal pemukiman. Tingginya jumlah spesies burung pada habitat hutan diduga berkaitan dengan ketersediaan pakan yang cukup melimpah, selain untuk melihat keanekaragaman spesies burung (Handari, Dewi dan Darmawan, 2012; Adelina, Harianto dan Nurcahyani, 2016).

\section{b. Indeks Kesamarataan}

Kesemarataan spesies dipengaruhi oleh jumlah individu dan jumlah spesies burung secara keseluruhan yang teramati di lokasi penelitian. Grafik jumlah jenis dan individu burung air di empat titik hitung disajikan pada Gambar 6. 


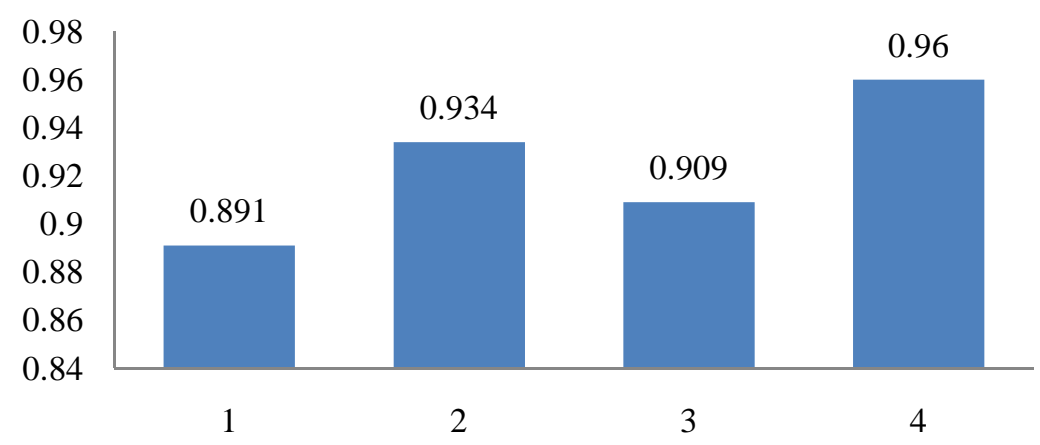

Gambar 6. Grafik jumlah jenis dan individu burung air di empat titik hitung

Kesamarataan spesies burung yang stabil menunjukkan bahwa spesies burung tersebar secara merata.Tingkat kesamarataan dan keanekaragaman spesies burung yang tinggi berhubungan erat dengan habitat burung untuk berlindung, bermain, bertengger, dan beristirahat, selain itu juga sebagai tempat ketersediaan pakan. Menurut Hadinoto, Mulyadi dan Siregar (2012) bahwa indeks kemerataan jenis burung yang memiliki nilai kurang dari satu menunjukkan bahwa terdapat dominasi satu atau beberapa spesies, artinya satu atau beberapa spesies memiliki jumlah individu yang lebih banyak dibandingkan dengan spesies yang lain.

\section{c. Nilai Kesamaan}

Nilai indeks kesamaan pada secara keseluruhan point count/stasiun pengamatan dapat dilihat pada tabel 3 yang artinya dalam point count/stasiun pengamatan ini banyak terdapat spesies yang sama. Indeks kesamaan ini akan memiliki nilai sama dengan 1 apabila terdapat kesamaan secara penuh atau jika serangkaian spesies dari kedua komunitas yang dibandingkan identik (Rohadi, Dewi dan Darmawan, 2011; Rohiyan, Setaiawan dan Rustiati, 2014). Nilai indeks kesamaan yang tinggi dikarenakan daya jelajah burung yang cukup luas. Selain itu kemungkinan dikarenakan jarak dari seluruh point count/stasiun pengamatanyang tidak terlalu jauh.

\section{Habitat Bagi Burung}

Habitat yang baik didalamnya mengandung bermacam-macam sumber pakan, memungkinkan memiliki jenis burung yang tinggi. Prinsipnya satwa liar memerlukan tempat-tempat yang digunakan untuk mencari makan, berlindung, beristirahat dan berkembangbiak (Alikodra, 2002). Jenis Burung dan Jenis Pakan Burung pada yang ditemukan pada penelitian disajikan pada Tabel 4.

Menurut Nugroho, Ningsih dan Ihsan (2013) perbedaan tipe habitat berpengaruh terhadap keanekaragaman jenis burung. Karena habitat beragam akan menyediakan sumberdaya yang cukup, baik sebagai tempat mencari makan, berlindung dan berkembang biak. Pada point count 1 dan 4 terdapat lebih sedikit spesies burungnya dibandingkan point count 2 dan 3, hal ini diduga karena pada lokasi tersebut terdapat gangguan berupa aktifitas manusia sehinggga membuat burung merasa terganggu dan terancam. Berdasarkan hal tersebut maka dapat diduga bahwa kondisi habitat dapat mempengaruhi perbedaan keanekaragaman spesies burung. Kondisi habitat yang berbeda menyebabkan perbedaan pemanfaatan habitat oleh beberapa burung sehingga ada beberapa burung hanya dapat ditemui di satu lokasi. 
Tabel 4. Jenis Burung dan Jenis Pakan Burung pada yang ditemukan di PT GMP

\begin{tabular}{llr}
\hline Jenis Pakan & \multicolumn{1}{c}{ Jenis Burung } & Jumlah \\
\hline Piscivora & Cangak Merah & 3 \\
& Belibis Kembang & \\
& Belekok Sawah & 3 \\
I dan P & Raja Udang Biru & \\
& Kuntul Kerbau & 2 \\
I, C, dan $P$ & Kuntul Kecil & Cekakak Sungai \\
& Cekakak Belukar & \\
I, G, dan $P$ & Kareo Padi & \\
& Mandar Besar & \\
& & \\
\hline
\end{tabular}

Keterangan : $C=$ Carnivora, $F=$ Frugivora, $G=$ Granivora, $I=$ Insectivora, $N=$ Nectarivora dan $P=$ Piscivora .

\section{KESIMPULAN DAN SARAN}

\section{A. Kesimpulan}

Berdasarkan penelitian analisis keanekaragaman jenis burung air di Divisi I dan Divisi II PT Gunung Madu Plantations Lampung Tengah, Oktober-November 2015 dapat disimpulkan bahwa:

1. Sepuluh spesies burung ditemukan dengan total 3420 individu yang berasal dari 4 famili dengan indeks keanekaragaman jenis $\left(H^{\prime}=2,137\right)$ yang berarti dalam kategori sedang dan dalam kondisi yang stabil dengan indeks kesamarataan $(\mathrm{J}=0,928)$.

2. Divisi I memiliki indeks keanekaragaman sedang $\left(H^{\prime}=1,890\right.$ dan $\left.H^{\prime}=1,997\right)$ dan dalam kondisi yang stabil dengan indeks kesamarataan $(\mathrm{J}=0,891$ dan $\mathrm{J}=0,960)$. Divisi II memiliki indeks keanekaragaman sedang $\left(\mathrm{H}^{\prime}=1,853\right.$ dan $\left.\mathrm{H}^{\prime}=2,052\right)$ dan dalam kondisi yang stabil dengan indeks kesamarataan $(\mathrm{J}=0,891$ dan $\mathrm{J}=0,934)$.

\section{B. Saran} adalah:

Berdasarkan penelitian yang telah dilakukan, saran-saran yang dapat diberikan

1. Pengelolaan Harus ditingkatkan agar tidak terjadi konversi lahan yang berlebihan tanpa kaidah yang menyebabkan turunnya kualitas habitat.

2. Perlu adanya penelitian lebih lanjut tentang ketersediaan pakan burung, populasi, kegiatan migrasi burung dan habitat bagi jenis burung tertentu di Divisi I dan Divisi II PT Gunung Madu Plantations Lampung Tengah.

\section{DAFTAR PUSTAKA}

Adelina, M., Harianto, S.P. dan Nurcahyani, N. 2016. Keanekaragaman jenis burung di Hutan Rakyat Pekon Kelungu Kecamatan Kota Agung Kabupaten Tanggamus. Sylva Lestari. 4 (2) : 51-60.

Alikodra, H. S. 2002. Pengelolaan Satwa Liar Jilid I. Buku. Institut Pertanian Bogor. Bogor. 363 p. 
Ayat, A. 2011. Panduan Lapangan Burung-burung Agroforest di Sumatera. Buku. World Agroforestry Centre. Bogor. 112 p.

Bibby, C., Jones, M. dan Marsden, S. 2000. Survei Burung. Buku. SMKG Mardi Yuana. Bogor. 34-35 p.

Darmawan, M. P. 2006. Keanekaragaman Jenis Burung pada Beberapa Tipe Habitat di Hutan Lindung Gunung Lumut Kalimantan Timur. Skripsi. Institut Pertanian Bogor. Bogor. $130 \mathrm{p}$.

Dewi, T. S. 2005. Kajian Keanekaragaman Jenis Burung di Berbagai Tipe Lanskap Hutan Tanaman Pinus (Studi Kasus: Daerah Aliran Sungai Ciliwung Hulu). Skripsi. Institut Pertanian Bogor. Bogor

Elfidasari, D. dan Junardi. 2005. Keragaman burung air di Kawasan Hutan Mangrove Peniti Kabupaten Pontianak. Biodeiversitas. 7 (1) : 63-66.

Elfidasari, D. 2007. Jenis interaksi intraspesifik dan interspesifik pada tiga jenis kuntul saat mencari makan di Sekitar Cagar Alam Pulau Dua Serang, Propinsi Banten.

Biodiversitas. 8 (4) : 266-269.

Firdaus, A. B., Setiawan, A. dan Rustiati, E. L. 2014. Keanekaragaman spesies burung di Repong Damar Pekon Pahmungan Kecamatan Pesisir Tengah Krui Kabupaten Lampung Barat. Sylva Lestari. 2 (2) : 1-6.

Hadinoto., Mulyadi, A. dan Siregar, Y. I. 2012. Keanekaragaman jenis burung di Hutan Kota Pekanbaru. Ilmu Lingkungan. 6 (1) : 25-42.

Handari, A., Dewi, B. S. dan Darmawan, A. 2012. Keanekaragaman Jenis Burung di Hutan Produksi Desa Gunung Sangkaran Kecamatan Blambangan Umpu Kabupaten Way Kanan. Skripsi. Universitas Lampung. Bandar Lampung. 105 p.

MacKinnon J., K. Philips, B. Van Balen. 2010. Burung-burung di Sumatera, Jawa, Bali, dan Kalimantan. Buku. Puslitbang Biologi-LIPI. Bogor. 509 p.

Nugroho, M. S., Ningsih, S. \& Ihsan, M. 2013. Keanekaragaman jenis burung pada Areal Dongi-dongi di Kawasan Taman nasional Lore Lindu. Warta Rimba. 1 (1) : 1-9.

Rohadi, D. 2011. Keanekaragaman Jenis Burung di Rawa Universitas Lampung. Skripsi. Universitas Lampung. Bandar Lampung. 129 p.

Rohiyan, M., A, Setiawan., E, L, Rustiati. 2014. Keanekaragaman jenis burung di hutan pinus dan hutan campuran Muarasipongi Kabupaten Mandailing Natal Sumatera Utara. Sylva Lestari. 2 (2). 89-98 p.

Rusmendro, H. 2009. Perbandingan keanekaragaman burung pada pagi dan sore hari di empat tipe habitat di wilayah Pangandaran, Jawa Barat. Vis Vitalis. 1 (2) : 8-16.

Watalee, H., Ningsih, S., dan Ramlah, S. 2013. Keanekaragaman jenis burung di Hutan Rawa Saembawalati Desa Tomui Karya Kecamatan Mori Atas Kabupaten Morowali. Warta Rimba. 1 (1) : 1-8. 